\title{
The Right of Access to Environmental Information in Ukraine and the EU
}

\author{
Viktor Ladychenko ${ }^{1}$, Liudmyla Golovko ${ }^{2}$
}

\begin{abstract}
The purpose of our scholarly work is to explore legal regulation of access to environmental information and public participation in environmental decision-making in Ukraine and the EU. The article considers how the Aarhus Convention has been implemented in EU member states and Ukraine, concentrating on the public access to information as a valid instrument for environmental protection. Taking part in the Erasmus + Jean Monnet Module "EU Environmental Policy and Law" we have analyzed the possibility of obtaining operative environmental information on the state of the environment in cities and villages of Ukraine. We also have studied European standards in the sphere of disclosure of environmental information and public participation, found some gaps in Ukrainian legislation and filled them in. We offer an interdisciplinary approach: integration of information law, environmental law, international law, human rights and national security. This will allow us to form a conceptual understanding of the legal regulation of information on the environment as an object of realization of information human rights and a component of national security in the context of environmental threats.
\end{abstract}

Keywords: Environmental information, information buman rights, sustainable development, EU environmental policy

\section{Legal Regulation of Access to Environmental Information in Ukraine}

Information support in the field of environmental protection is one of the main elements of the state's obligation to create favorable conditions for life and health of people. Without reliable and complete information on the state of the environment it is impossible to speak about the proper implementation of other environmental rights of the individual. Thus, the right to environmental information is the right of a person which promotes the exercise of his right to a prosperous environment, which is why it occupies a special place among the fundamental rights and freedoms of citizens, characterizing the degree of development of a modern democratic state. Informing the public raises awareness of people and their understanding of environmental problems.

A number of regulatory legal acts in Ukraine are devoted to the problem of access to environmental information. In particular, they include the Laws of Ukraine "On Information", "On Access to Public Information", "On Environmental Protection", "On Environmental Impact Assessment", Resolution of the Cabinet of Ministers "On Ensuring Public Participation in the Formation and Implementation of State Policy" and "On the Procedure for Disclosing Information on Activities of Executive Bodies on the Internet".

| ${ }^{1}$ Doctor of Law, professor, head of the Department of International Law and Comparative Law of the National University of Life and Environmental Sciences of Ukraine

2 $2 \mathrm{PhD}$., associate professor of the Department of International Law and Comparative Law of the National University of Life and Environmental Sciences of Ukraine 
According to the Law "On Environmental Protection", information on the state of the environment (environmental information) is any information in written, audio-visual, electronic or other material form about:

- the state of the environment or its objects;

- land, water, subsoil, atmospheric air, flora and fauna and the level of their pollution;

- biodiversity and its components, including genetically modified organisms and their interaction with the objects of the environment;

- sources, factors, materials, substances, products, energy, physical factors (noise, vibration, electromagnetic radiation, radiation) that affect or can affect the state of the environment and human health;

- threat of occurrence and causes of environmental emergencies, the results of elimination of these phenomena, recommendations on measures aimed at reducing their negative impact on natural objects and human health;

- environmental forecasts, plans and programs, activities, including administrative, state environmental policy, legislation on environmental protection;

- costs associated with the implementation of environmental activities from environmental funds, other sources of financing, economic analysis conducted in the decision-making process related to the environment. The main sources of such information are environmental monitoring data, natural resource cadastres, registers, automated databases, archives, as well as certificates issued by authorized state bodies, local governments, public organizations, individual officials (The Law "On Environmental Protection", 1991).

Despite the seemingly expanded list of elements of environmental information contained in Ukrainian legislation, the national definition does not include all elements compared with provisions of the Aarhus Convention. For example, it does not contain "costbenefit and other economic analyses and assumptions used in environmental decisionmaking"(Aarhus Convention, 1998), which, of course, is a disadvantage. The above mentioned definition does not also include information about accidents, catastrophes, dangerous natural phenomena and other emergencies that have occurred or can occur and threaten the safety of people.

According to the Law, the public is informed about the state of the environment in the form of an annual National Report on the state of the natural environment in Ukraine, which, after its consideration by the Supreme Council of Ukraine, is published and posted on the Internet. The creation of a similar document is also envisaged for the regional state administrations. Other articles of the Law provide for "systematic information of the population through the mass media on the state of the environment", "immediate information about emergency environmental situations and ensuring free access to environmental information", etc. Without a specific timetable and responsible executors these provisions are of declarative nature and citizens of Ukraine can only expect to receive environmental information only annually (Radovenchyk et al., 2016).

\section{The State of Environmental Information Disclosure in Ukraine}

Unfortunately, we have to state that the population of Ukraine generally receives incomplete, inaccurate, scientifically unjustified information about the state of the 
environment, individual natural objects, the quality of water and air, use of chemical products in agriculture, melioration, accidents or disasters. Sometimes such information is even hidden.

Thus, it can be concluded that the performance of the function of active informing the citizens of Ukraine about the state of the environment by the authorities remains problematic. The lack of full access to environmental information has tangible consequences for citizens, their health and well-being, and also hinders environmental protection processes.

In Ukraine there is a problem of concealing environmental information on the state of the environment from the side of state authorities and local self-government. One of the reasons for this state of affairs is the imperfection of legislation.

According to the part 4 of the article 4 of the Aarhus Convention, a request for environmental information may be refused if the confidentiality of commercial and industrial information, where such confidentiality is protected by law in order to protect a legitimate economic interest. Within this framework, information on emissions which is relevant for the protection of the environment shall be disclosed. This norm is successfully used by the Ministry of Natural Resources for concealing certain results of environmental expertise, which has already attracted public attention.

In the last years the law on access to environmental information has not been systematically implemented in Ukraine. The Ministry of Ecology and Natural Resources of Ukraine does not develop or publish the annual National Report on the state of the environment. As of March 2018, the latest National Report was posted on the official web portal of the Ministry of Ecology and Natural Resources in 2015. Within last two years the report was not submitted to the Supreme Council of Ukraine for consideration and was not published, although this is provided by law.

In accordance with the current legislation, the Ministry of Regional Development has to prepare each year a National Report on the quality of drinking water and the state of drinking water supply. But the last known report is dated 2009.

Increasingly, legislative guarantees for access to information on environmental impact assessment of investment projects are being violated. Not always citizens can protect their right to environmental information in the courts. The next problem in Ukraine is concealing of environmental information not only from the side of public authorities, but also from the side of private sector.

\section{Positive EU Experience, which Should Be Implemented in Ukraine}

By ratifying the Aarhus Convention in 2005 the EU committed itself to guaranteeing access to environmental information, public participation in environmental decision making, and broad access to justice in environmental matters both at the national and the EU level (Schoukens, 2015). At regional level European Union has taken important steps to align Community legislation with provisions of Aarhus Convention. Namely, Community environment policy is based on integration of environmental protection into other policies and aims to protect the environment for future generations (Luttenberger, 2004).

Furthermore court decisions in the EU have emphasized the importance of public 
participation to environmental justice and democracy (Bonorris, 2010). Another positive EU experience which should be implemented in Ukraine derives from the EU Directive on Environmental Liability, which allows the public and nongovernmental environmental organizations to request competent authorities to intervene in cases of environmental damage or imminent threat (Dellinger, 2011). Based on the example of EU member states Ukrainian legislation should also include provisions, which would enable the public to influence decisions concerning the necessary preventive measures. Non-governmental organizations working at the environmental protection and persons who suffered the adverse effects or are able to experience the damage from environmentally hazardous activities should have the right to require the competent authority to take the necessary preventive measures. This requirement is necessary because in Ukraine the public has actually no real impact on the environmentally significant decisions (Ladychenko, 2017).

Public participation can help by adding another expert voice to the democratic discourse as well as to lawmaking and law enforcement processes (Toth, 2010). When discussions and negotiations on the protection of the environment, on the balancing of ecological with other interests take place in the remoteness of administrative offices or behind closed windows, the environment almost always is the loser; only when the discussions are transparent and public, is there a chance that the considerations of the protection of the environment prevail over vested interests. This aspect links the citizen's right of access to information which is directed against public administration, to the specific concern for the environment (Krämer, 2013).

The right to access to environmental legislation is enshrined in Ukrainian legislation, but the right to effective and accessible procedures to enable individuals to seek all relevant and appropriate environmental information, and to participate in environmental decision making, when their right to life, or/and their right to respect for private and family life, are threatened is not legally regulated. That is why it is necessary to use EU experience in this sphere. Procedural environmental rights provide several benefits to the public. They serve to: raise awareness of the state of the environment and possibly motivate behavioural change; facilitate gathering of information for sounder environmental decision-making, which in turn likely increases legitimacy of, and buy-in into, resulting decisions; facilitate accountability of government and others (including private entities, to some extent) as regards environmental protection throughout the policy process, with increased scrutiny likely to lead decision makers to give greater weight to environmental considerations and adhere more closely to environmental policy and law); and enable improved implementation and enforcement of environmental law (in a climate of limited state resources and given the widespread nature of environmental harm), by empowering the public to control public authorities' environmental decisions and protect their rights dependent on a healthy environment which may be/have been affected by the proposed decision (Kimber, 1998). But at the same time public participation requires that people and population groups need to understand the policies in order to choose the ones that match their needs (Squintani, 2016). 


\section{Conclusions}

Legislation of Ukraine on access to environmental information has several shortcomings. It does not contain specific timetable for disclosure of environmental information to the public and responsible executors. There is no procedural order for providing environmental information, leading to irresponsibility of state bodies. There is also lack of information exchange between the authorities. For example, the Ministry of Ecology and Natural Resources of Ukraine does not have a "Regulation on the procedure for providing environmental information". These shortcomings, in our opinion, should be eliminated.

In Ukraine the public has actually no real impact on the environmentally significant decisions. In EU member states citizens have mainly right to information and consultations. Higher levels of participation (such as involvement or cooperation) are recommended in the guidelines issued by ministries, but they are not obligatory to the competent authorities. Here there are perspectives for further development, because public participation may contribute to a more informed planning process.

\section{References}

Aarhus Convention on access to information, public participation in decision-making and access to justice in environmental matters (1998). Aarhus (Denmark), June.

Bonorris, S., Targ, N. (2010). Environmental Justice in the Laboratories of Democracy, 25. Retrieved from: https://gov.uchastings.edu/public-law/docs/NRE_FA10_bonorris_targ.pdf

Dellinger, M.F. (2011). Ten Years of the Aarhus Convention: How Procedural Democracy Is Paving the Way for Substantive Change in National and International Environmental Law. Retrieved from: https://ssrn.com/abstract $=2004513$ or http://dx.doi.org/10.2139/ssrn.2004513

Kimber, C. (1998). Understanding Access to Environmental Information: The European Experience. Law in Environmental Decision-Making: National, European and International Perspectives, 139, 142-143.

Krämer, L. (2013). The EU, access to environmental information and the open society. Environmental Law Network International, 38-43

Ladychenko, V., Golovko, L. (2017). Implementation of European Environmental Policy in Ukraine: Problems and Prospects. European Journal of Sustainable Development, Volume 6, № 3, 333-339

Luttenberger, A., Rukavina, B. (2004). The right to access to information on environmental matters. Energy and the Environment, 257-263.

Radovenchyk V.M., Radovenchyk Ya.V., Katchula I.H. (2016). Access to environmental information in Ukraine. Bulletin of the National Technical University of Ukraine "Kyiv Polytechnic Institute". Chemical engineering, ecology and resource conservation, 1, 75-81.

Schoukens, H. (2015). Access to Justice in Environmental Cases after the Rulings of the Court of Justice of 13 January 2015: Kafka Revisited? Utrecht Journal of International and European Law, 31(81), Retrieved from: http://dx.doi.org/10.5334/ujiel.di

Squintani, L., Vanheusden., B. (2016). EU Environmental and Planning Law Aspects of Large-Scale Projects. Cambridge: Intersentia Cambridge.

The Law "On Environmental Protection" (1991). Bulletin of the Supreme Council of Ukraine. - №. 41. St.546.

Toth, B. (2010). Public Participation and Democracy in Practice - Aarhus Convention Principles as Democratic Institution Building in the Developing World. Journal of Land Resources \& Environmental Law, 30, 295-330. 